\title{
Utilization of Available Facilities of Computer Aided Teaching in Secondary Level School of Nepal \\ Bhimsen Giri ${ }^{1}$ and Megha Raj Dhakal ${ }^{2}$
}

${ }^{1} \mathrm{PhD}$ Scholar, Mewar University, Rajasthan, India,

${ }^{2}$ Research Supervisor, Associate Professor, Nobel College, Pokhara University, Kathmandu, Nepal.

\section{Corresponding Author}

Bhimsen Giri

Email: bhimsen.giri@ rec.edu.np

\section{ABSTRACT}

Computer aided teaching is modern technical teaching practice which is gradually replacing the traditional teaching practice by using the blackboard, chalk and duster. Nepalese secondary level schools are also gradually practicing the computer aided teaching system. The growing completion of private boarding school also compels to manage such modern facilities to attract the students. The facilities are comparatively weak in public school because the public school depends on the government funding. The study measured the utilization practice of available facilities of computer aided teaching in secondary level school. The study was conducted in Dang and Pyuthan district of Nepal. In total 578 students were selected from the different schools of two district by using the simple random sampling. The result shows that there was significant $(p=$ .019) different between the students of two districts regarding their practice to spend the total days in a week in computer lab, use of internet in school and types of computer users whereas there was no difference in use of computer in leisure time and facility of soft copy of reading materials provided by school. The comparatively, computer and internet use practice is found better in Dang district than the Pyuthan though in totality, the result of computer aided teaching practice is not satisfactory. So, the concerned authority of public and private school of both districts should enhance the capacity of management and teachers to maximize the facilities of computer aided teaching practice in Nepal.

\section{KEYWORDS}

Computer aided teaching, Facilities, Nepal, Secondary, and Utilization

\section{INTRODUCTION}

Computer is the latest technological innovation to be applied to education (Sharma \& Vohra, 1998, p. 1). Computer was introduced in Nepal in the year 1972 only. It was introduced by His Majesty's government for the population census of 1972 (2028 B.S) Nowadays, Students are given computer education from school level. Public access on modern communication and technology is increasing day by day. The data of Nepal shows that access to public or private communication has changed quite drastically $-50 \%$ households have radio, and similar numbers own a TV set, $75 \%$ use mobile 
telephone which is a sharp increase from around 6\% in 2006 and $9 \%$ have non-mobile telephone (UNESCO, 2015, p. 5).

More recently, however, schools have become interested in using tool softwareapplications programs, such as word processing, which can support classroom work (in this case, writing), and which have the potentiality of changing the nature of work (in this case, for example, toward a greater emphasis on editing and on joint writing projects)(Sharma \& Vohra, 1998, p. 162). Students need computers for researching material. Libraries are often extremely timeconsuming, and they are not easily accessible for every student. The Internet is perhaps the most convenient and efficient method to browse information and analyze its usage. Additionally, most universities allow their students free access to their Web-based archives. Asking for help from teachers and other students through email or simply brainstorming ideas is another reason computers are important for students. Computer has also revolutionized the whole process of education. Currently, the classrooms, libraries, and museums are efficiently utilizing computers to make the education much more interesting. Unlike recorded television shows, computer-aided education (CAE) and Computer Based Training (CBT) packages are making learning much more interactive ( ITL educational solution, 2009, p. 20).

The history of computer education in Nepal can be traced as early as 1930s, when the Technical Training Institute was established. It was later reformed as current Institute of Engineering in 1972. Since then Nepal has stridden gradually in Technical education (Shah, 2012).A computer may be defined as "an electronic machine which is fast and accurate symbol or data manipulating system. As computer has a lot of applications in almost all fields, their presence cannot be ignored. People feel comfortable and easy with the presence of computers in the modern world (Rajasekar, 2007, p. 1). As Kukil stated that computer-based instruction (CBI) is important to drill, tutor, and test students and to manage instructional programs. In recent years these CBI programs have been used increasingly in schools to supplement or replace more conventional teaching methods (1991, p. 75). Phillips has said that the computer acts as delivery system, it stimulates and motivates the students. It puts demands on the students' to make them active, creative and exploratory .It is a powerful tool since it puts demands on the students' cognitive functioning (1985).

In the Nepalese context, infrastructure facilities are poor in secondary level school. All schools have no adequate facility of computer aided education. Poor school building, lack of classrooms, unavailability of the textbooks in time, lack of school at proper place and so forth are physical factors contributing for the poor performance of the community schools. Likewise, centralized curriculum for the diverse population, monolingual method of instruction, lack of dedication from teacher's side, traditional pedagogical strategy in teaching learning, are some of the educational factors hindering the quality of the public schools. Moreover, poverty and deeply rooted exclusion of caste, gender and marginalized groups from the society are also contributing for poor performance (Parajuli \& Das, 2013, p. 153). Joshi said accesses of internet is expensive and more than $80 \%$ of the populations are living in remote area and there is no accessible of internet by which students as well as teachers of that area are not facilitating by it. Infrastructure of schools 
are in traditional types like buildings, rooms, furniture so government should fund for modern ICT based infrastructure. School staffs and computer teachers have not ideas of brands of computers; safely use of computer and subject related applications hence related stakeholders should provide training and awareness program for them(Joshi, 2013).

From the general observation, it can be seen that both public and private schools are managing the computer. Students are being charged the extra fee for computer class also. So, it is assumed that there are computer facilities in all school but the question is whether the available facilities are properly used or not? So, the major research objective of this study is to identify the utilization practice of available computer facilities in secondary level school.

\section{MATERIALS AND METHOD}

The study was conducted in the Dang and Pyuthan districts of Mid-western Region of Nepal. The both types of public and private secondary levels schools were selected for the study. The students were the primary respondents of this study to know their practice of using the available computer aided teaching facilities. The simple random sampling technique was adopted to select the 578 students. Structured questionnaire survey was done to collect the data. The instruments were pretested to ensure the reliability and validity. The final collected data were edited then put in the statistical software for analysis. The independent sample t-test and Pearson Chi-Square test was used to identify the differences between the two districts.

\section{RESULTS AND DISCUSSION}

It is said that 'practice makes a prefect man' so only availability of facility is not important but it should be in proper use for the betterment of learning and performance of students. Stocking of good cannot be beneficial so the study asked to teachers and students about their practice to use the available facilities of school.

The study has analyzed the data on the basis of geographical differences of school because in the context of infrastructure development of Nepal is affected by its geographical variation also. So, the study aims to identify the effect of geographical location on the availability and utilization of available facilities of school.

\section{District wise Time spend in computer lab}

A computer lab is a space which provides computer services to a defined community. Computer labs are typically provided by libraries to the public, by academic institutions to students who attend the institution, or by other institutions to the public or to people affiliated with that institution. Users typically must follow a certain user policy to retain access to the computers. This generally consists of the user not engaging in illegal activities or attempting to circumvent any security or content-control software while using the computers. Table 1 below shows the district wise time spends in computer lab. Were, there is slight difference in mean value of Dang and Pyuthan of total days spend in computer lab in a week and it shows the significant relation. Whereas, there is slight difference in the mean value of Dang and Pyuthan of total hours spend in computer lab in a week. 
ISSN: 2362-1303 (Paper) | eISSN: 2362-1311(Online)

JOURNAL OF ADVANCED ACADEMIC RESEARCH (JAAR)

December 2017

Table 1: District wise Time spend in computer lab

\begin{tabular}{|c|c|c|c|c|c|c|c|}
\hline \multicolumn{8}{|c|}{ Independent Samples Test } \\
\hline \multicolumn{2}{|l|}{ Districts } & $\mathrm{N}$ & Mean & $\mathrm{T}$ & df & $\begin{array}{l}\text { Sig. } \\
\text { (2- } \\
\text { tailed) }\end{array}$ & Result \\
\hline \multirow{2}{*}{$\begin{array}{l}\text { Total days spend } \\
\text { in computer lab in } \\
\text { a week }\end{array}$} & Dang & 298 & 2.5302 & \multirow[b]{2}{*}{2.344} & \multirow[b]{2}{*}{565.972} & \multirow[b]{2}{*}{.019} & \multirow[b]{2}{*}{ Significant } \\
\hline & Pyuthan & 280 & 2.2143 & & & & \\
\hline \multirow{2}{*}{$\begin{array}{l}\text { Total hours spend } \\
\text { in computer lab in } \\
\text { a week }\end{array}$} & Dang & 298 & 2.5362 & \multirow{2}{*}{-1.533} & \multirow{2}{*}{576} & \multirow{2}{*}{.126} & \multirow{2}{*}{ Not Significan } \\
\hline & Pyuthan & 280 & 2.8893 & & & & \\
\hline
\end{tabular}

Source: Field Survey, 2017

The independent sample t-test shows that there was significant difference between the respondents of Dang and Pyuthan district regarding the total days spend in computer lab in a week whereas there was no difference in total hours spend in a week. There was slightly higher number of days was spend by the respondent of Dang in computer lab whereas the total hours spend by respondents were found similar in Dang and Pyuthan district.

\section{District wise Use of Computer}

The Table 2 illustrates the district wise use of computers. It clearly describes how the computer has been used by the students. In survey it was found that in both the district only one computer has been used in each school by the students. In Dang the maximum percentage (43.6\%) which shows that one computer each has been used by the students similarly, the minimum percentage $(15.4 \%)$ which shows that only one computer has been used by maximum students. Contrary to this, in Pyuthan $34.6 \%$ of respondent has said that in this district only one computer has been used by two students and $20.4 \%$ said that only one computer has been used by total three students. In totality it shows that in both the district only one computer has been used by maximum number of students.

Table 2: District wise Use of Computer

\begin{tabular}{|c|c|c|c|c|c|}
\hline & \multicolumn{2}{|c|}{ Districts } & \multirow[t]{2}{*}{ Total } \\
\hline & & & Dang & Pyuthan & \\
\hline \multirow{8}{*}{$\begin{array}{l}\text { How the } \\
\text { computer } \\
\text { has been } \\
\text { used }\end{array}$} & \multirow{2}{*}{ One student $=1$ computer } & Count & 130 & 61 & 191 \\
\hline & & $\%$ within district & 43.6 & 21.8 & 33.0 \\
\hline & \multirow{2}{*}{ Two students $=1$ computer } & Count & 102 & 97 & 199 \\
\hline & & $\%$ within district & 34.2 & 34.6 & 34.4 \\
\hline & \multirow{2}{*}{ Three students $=1$ computer } & Count & 20 & 57 & 77 \\
\hline & & $\%$ within district & 6.7 & 20.4 & 13.3 \\
\hline & \multirow{2}{*}{$\begin{array}{l}\text { More than three students }=1 \\
\text { computer }\end{array}$} & Count & 46 & 65 & 111 \\
\hline & & $\%$ within district & 15.4 & 23.2 & 19.2 \\
\hline
\end{tabular}

Vol. 4. No. II

www.phdcentre.edu.np 


\begin{tabular}{|l|l|l|l|l|}
\hline \multirow{2}{*}{ Total } & Count & 298 & 280 & 578 \\
\cline { 2 - 5 } & $\%$ within district & 100.0 & 100.0 & 100.0 \\
\hline \multicolumn{5}{|c|}{ Chi-Square Tests } \\
\hline & Value & Df & Asymp. Sig. (2-sided) \\
\hline Pearson Chi-Square & 45.567 & 3 & .000 \\
\hline
\end{tabular}

Source: Field Survey, 2017

The statistical result of Pearson Chi-Square test shows that there was significant association between the Dang and Pyuthan district regarding the use of computer because $\mathrm{P}=.000$ which is less than .05 significant levels. In totality, computer facility for student is found comparatively better in Dang than Pyuthan district. For the effective learning, every student should be provided one computer during the computer class so that they will have adequate time to learn the computer skill, use of internet and email, typing skill, design and formatting of documents. The availability of number of computer depends upon the economic capacity of school also.

\section{District wise Use of computer in leisure time}

Table 3 below depicts the district wise use of computer in leisure time. Computer is important for the students who are more interested to learn about the computer and its use for the learning. There is double benefit from the use of computer, on the one hand s/he will have good skill of technology as well as they can prepare the home work, e-copy of reading materials, prepare e-book. In Dang and Pyuthan district it was found that the student used computer less according to their will which is $71.5 \%$ and $69.3 \%$. It means that the students are only allowed to use the computers as instructed by their teachers.

Table 3: District wise Use of computer in leisure time

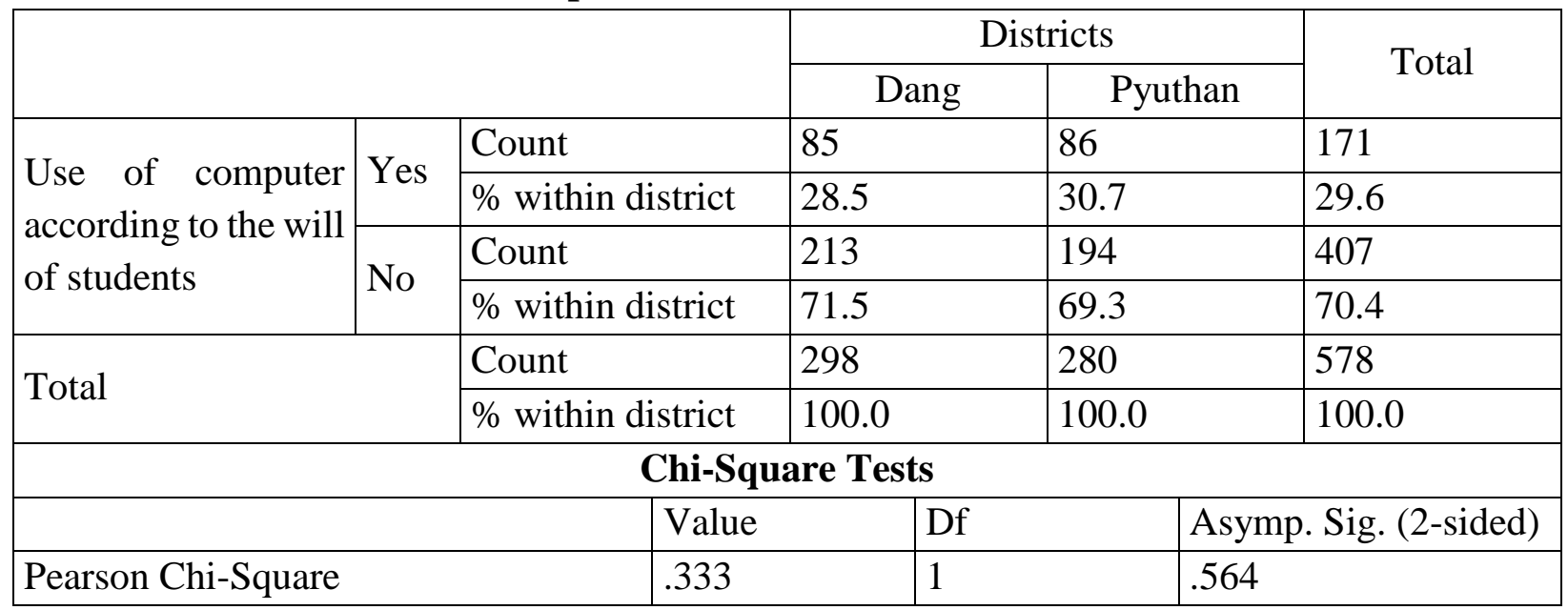

Source: Field Survey, 2017

The statistical result of Pearson Chi-Square test shows that there was no significant association between the Dang and Pyuthan district regarding the use of computer by students in their leisure time because $\mathrm{P}=.564$ which is greater than .05 significant levels. It indicates that there 
was similar practiced of use of computer in leisure time in both Dang and Pyuthan district. The both districts have similar characteristic from the development perspective.

\section{District wise Use of internet in school}

Internet has become an important part of life that most of us use it every day. It is a wonderful place for studying, communicating, entertaining, working as well as the biggest information source in the world. Thus, Internet provides many benefits and helps improve living quality of people everywhere. In this article, Vkool.com will give you useful knowledge about meaning and benefits of internet, and how you can use internet effectively. Internet is helpful for the students that forgot work, missed a lecture or couldn't remember an assignment were out of luck until talking face to face with a teacher or a classmate. However, the Internet allows instantaneous connection to your classmates and teachers. Improving communication between students and teachers allows teachers to assist students without having to stay after class. It also allows for students to have greater efficiency when working on projects with their peers when everyone cannot attend or asking for clarification when something is unclear. So internet plays an important role in teachers and even students' life. Table 4 illustrates the district wise use of internet in school where, in both the district Dang and Pyuthan the facility of internet has not been used as expected i.e $71.5 \%$ in Dang and 93.9\% in Pyuthan.

Table 4: District wise Use of internet in school

\begin{tabular}{|c|c|c|c|c|c|c|c|c|}
\hline & \multicolumn{4}{|c|}{ District } & \multirow[t]{2}{*}{ Total } \\
\hline & & & & \multicolumn{2}{|c|}{ Dang } & \multicolumn{2}{|l|}{ Pyuthan } & \\
\hline \multirow{4}{*}{$\begin{array}{l}\text { Use of } \\
\text { internet in } \\
\text { school }\end{array}$} & \multirow{2}{*}{ Yes } & \multicolumn{2}{|l|}{ Count } & \multicolumn{2}{|l|}{85} & \multicolumn{2}{|l|}{17} & 102 \\
\hline & & \multicolumn{2}{|l|}{$\%$ within district } & \multicolumn{2}{|l|}{28.5} & \multicolumn{2}{|l|}{6.1} & 17.6 \\
\hline & \multirow{2}{*}{ No } & \multicolumn{2}{|l|}{ Count } & \multicolumn{2}{|l|}{213} & \multicolumn{2}{|l|}{263} & 476 \\
\hline & & \multicolumn{2}{|l|}{$\%$ within district } & \multicolumn{2}{|l|}{71.5} & \multicolumn{2}{|l|}{93.9} & 82.4 \\
\hline \multirow{2}{*}{\multicolumn{2}{|c|}{ Total }} & \multicolumn{2}{|l|}{ Count } & \multicolumn{2}{|l|}{298} & \multicolumn{2}{|l|}{280} & 578 \\
\hline & & \multicolumn{2}{|l|}{$\%$ within district } & \multicolumn{2}{|l|}{100.0} & \multicolumn{2}{|l|}{100.0} & 100.0 \\
\hline \multicolumn{9}{|c|}{ Chi-Square Tests } \\
\hline & & & \multicolumn{2}{|l|}{ Value } & $\mathrm{Df}$ & & \multicolumn{2}{|c|}{ Asymp. Sig. (2-sided) } \\
\hline \multicolumn{3}{|c|}{ Pearson Chi-Square } & \multicolumn{2}{|l|}{50.073} & 1 & & \multicolumn{2}{|c|}{.000} \\
\hline
\end{tabular}

Source: Field Survey, 2017

The statistical result of Pearson Chi-Square test shows that there was significant association between the Dang and Pyuthan district regarding the use of internet in school because $\mathrm{P}=.000$ which is less than .05 significant levels. The use of internet in school was significantly different in Dang and Pyuthan district. The data shows that internet use practice is found better in Dang district than Pyuthan though the result is not satisfactory because the internet is important to search the new knowledge but the access is very low for the student. Student can learn many out knowledge from the internet so it should be increased in all school. Student should be taught about the proper 
use of internet so that they can do their homework effectively. Innovative knowledge can be gain from the internet use.

\section{District wise Users of computer in school}

Computer is not only important to student but also to the teachers as well. The below Table 5illustrate the time spend by the teacher, student and others in school. In Dang we can see that more time has been used by the teachers' i.e $37.6 \%$ and less time i.e. has been used by others. Similarly, regarding Pyuthan $47.1 \%$ of computers is used by both the teachers and students where, only $7.5 \%$ of computers is been used by others. So in totality we can say that both the teachers and students are using the computers for different purpose.

Table 5: District wise Users of computer in school

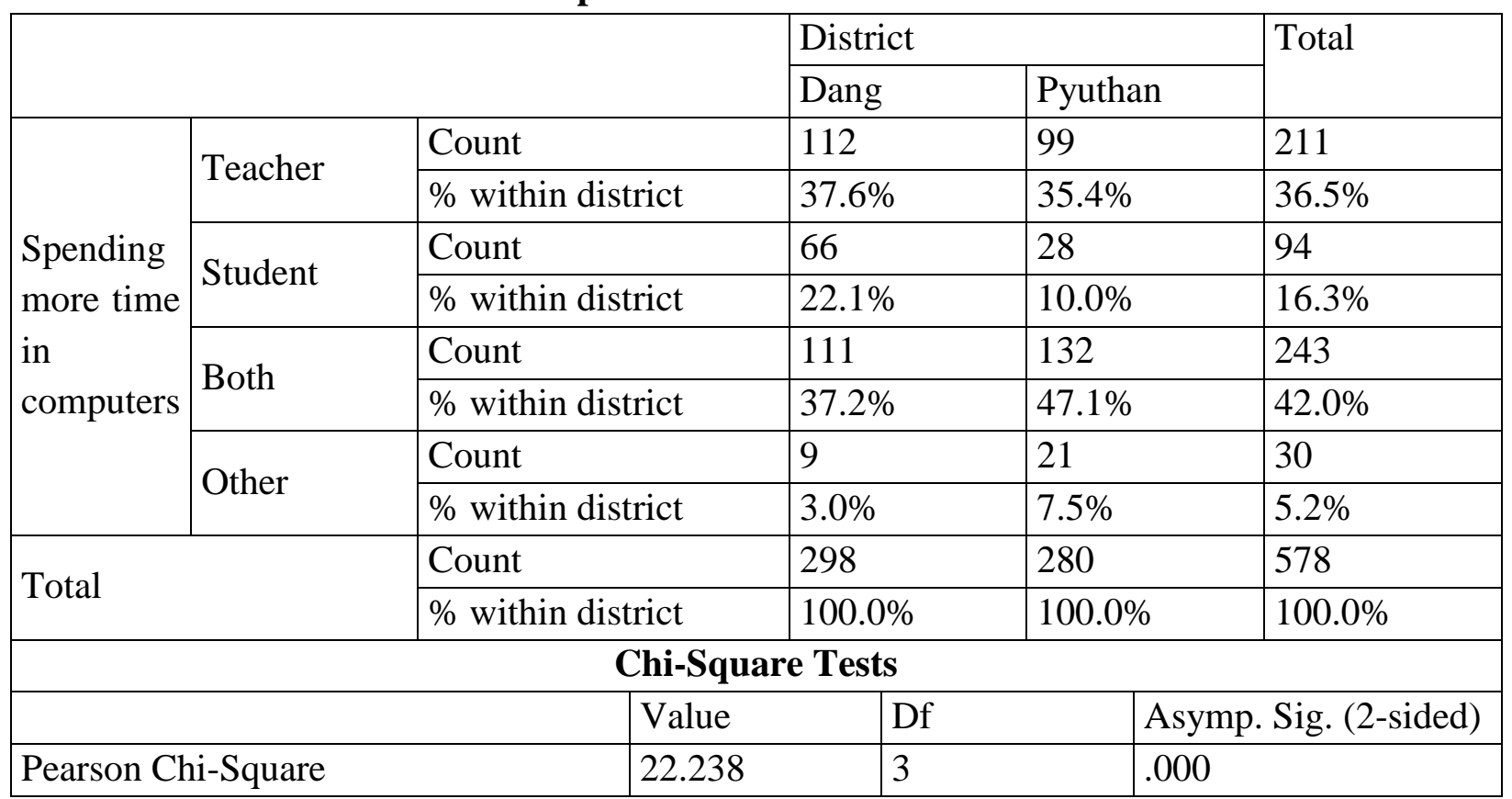

Source: Field Survey, 2017

The statistical result of Pearson Chi-Square test shows that there was significant association between the Dang and Pyuthan district regarding the user of computer in school because $\mathrm{P}=.000$ which is less than .05 significant levels. The result indicates that nature of frequency of computer users is significantly different in both districts. Student as a user of computer was significantly higher in Dang district than the Pyuthan though result is not satisfactory because less than 25\% said they spend more time in computer than other. Computer use practice is very important for student to increase their technical knowledge which will be supporting to earn the better mark in final exam.

\section{District wise Printed and soft copy of reading materials provided by school}

In this $21^{\text {st }}$ century computer plays the vital role in student's life. Previously only book was the medium of knowledge but nowadays with the help of computers and internet we can know as many 
things as we like. Technology is developing very fast than we think in today's world many of the schools are running their education system in computer based due to which the students can easily get success in their work and even it seems to increase the creativity of the students as because they can get tremendous knowledge regarding their subjects. The Table 6 depicts the district wise printed and soft copy of reading materials provided by the school. While doing survey it was found that in both the district many students said that the school hasn't been provided any type of soft copy or reading materials i.e. 63.1\% in Dang and 56.4\% in Pyuthan. Similarly, 36.9\% of Dang and $43.6 \%$ of Pyuthan students said the school has provided some of the printed or soft copy reading materials to them.

Table 6: District wise Printed and soft copy of reading materials provided by school

\begin{tabular}{|c|c|c|c|c|c|c|c|}
\hline & & & & Distri & & & Total \\
\hline & & & & Dang & & Pyuthan & \\
\hline Computerized printed & Y & Count & & 110 & & 122 & 232 \\
\hline or soft copy of & Ies & $\%$ with & istrict & 36.9 & & 43.6 & 40.1 \\
\hline reading material & & Count & & 188 & & 158 & 346 \\
\hline $\begin{array}{l}\text { provided by the } \\
\text { school }\end{array}$ & No & $\%$ with & istrict & 63.1 & & 56.4 & 59.9 \\
\hline Total & & Count & & 298 & & 280 & 578 \\
\hline Total & & $\%$ with & istrict & 100.0 & & 100.0 & 100.0 \\
\hline Chi-Square Tests & & & & & & & \\
\hline & & & Value & & Df & Asyr & g. (2-sided) \\
\hline Pearson Chi-Square & & & 2.664 & & 1 & .103 & \\
\hline
\end{tabular}

Source: Field Survey, 2017

The statistical result of Pearson Chi-Square test shows that there was no significant association between the Dang and Pyuthan district regarding the printed and soft copy of reading materials provided by school because $\mathrm{P}=.103$ which is greater than .05 significant levels. The response of students shows that there was similar situation in both districts regarding the facility of e-copy or printed copy of reading materials provided by the school. The result is not satisfactory because less than $50 \%$ reported the facility of soft copy of reading materials.

\section{CONCLUSIONS}

The study has explored the utilization practice of computer facilities in secondary level school of Dang and Pyuthan district of Nepal. Various socio-economic characteristics of these both districts are very similar so study found the significantly similar types of understanding and knowledge of computer aided teaching practice among the school teachers and management. Private schools have slightly better facility of computer aided teaching than the public school but there was no significant effect of location. The use of computer practice is slightly better in Dang district than the Pyuthan but use of computer in leisure time and facility of soft copy of reading materials provided by school was similar in both districts. The internet facility in school of Dang district is 
better than the Pyuthan district. The school management should increase the accessibility of computer for students to develop the technical skill in student. This is the age of modern technology so computer aided teaching practice should be improved in secondary level school. The current computer use practice is not satisfactory in both Dang and Pyuthan district. The computer skill of teacher should also be enhanced.

\section{REFERENCES}

ITL educational solution. (2009). introdction to computer science. delhi: Dorling kindersley (india) pvt.Ltd., licenseees of pearson education in south asia.

Joshi, D. R. (2013). Policies, Practices and Barriers of ICT Utilization in School Education in Nepal. Banaras: Banaras Hindu University.

Kulik, C.-L. C. (1991). Effectiveness of Computer-Based Instruction: An Updated Analysis. Computers in Human Behavior, 7, 75-94.

Parajuli, D. R., and Das, T. (2013). Performance Of Community Schools In Nepal: A Macro Level Analysis. INTERNATIONAL JOURNAL OF SCIENTIFIC and TECHNOLOGY RESEARCH, 2 (7), 148-154.

Phillips, M. (1985). Educational Technology in the Next decade: An ELT perspective. In M. P. C. Brumfit, Computers in English language teaching (Eds.). Oxford Progrmer Press.

Rajasekar, D. S. (2007). Computer Education and Educational Computing. Hyderabad: Neelkamal Publication PVT. LTD.

Shah, S. ( 2012, Sep 30). Retrieved Feb 21, 2017, from IT Training Nepal Pvt. Ltd.: http://www.ittrainingnepal.com/computer-education/computer-education-in-nepal/

Sharma, S. R., and Vohra, A. (1998). Computer in Education. New Delhi: Anmol publication pvt. ltd.

UNESCO. (2015). EDUCATION FOR ALL - NATIONAL REVIEW REPORT| 2001-2015. Sanepa, Lalitpur: Government of Nepal Ministry of Education and UNESCO. 